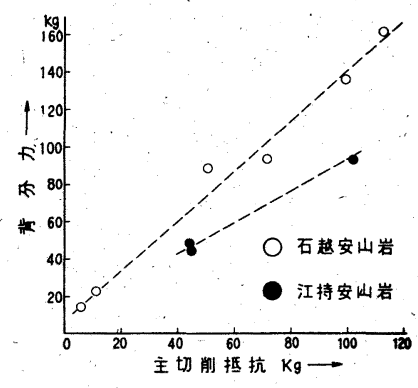

第1圆背分力と主切削 抵抗との関係

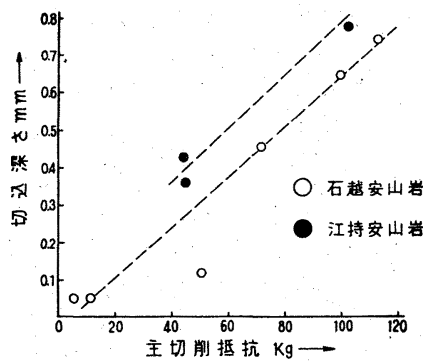

事2图・切込梁さと主切削 抵抗との関係

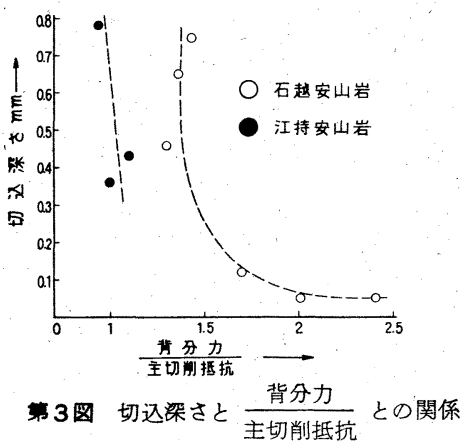

を示している。なおてれらの図の各測点は平均值をもっ て表示したものである。

筆者らはさらに花崗岩, 砂岩などについても切削実験 を行ない, 各試料岩石の物理的性質との関連において考 察を試みたのでそれらの結果につんて述べる。 の比をとったるので，切込深さが増加すると背分力と主 切削抵抗との比は減少しほ度一定の值になるような傾向

\title{
1115 ボーリングに関する研究
} 穿孔特性について—-

\author{
秋田大学鎕山学部助教授 $\bigcirc$ 谷口啓之助(正会員) \\ 秋田大学鉱山学部大学院学生一 一 健吾
}

\section{1. まえが き}

回転式コアボーリングに晾ける岩石の穿孔特性の研究 に当たり，筆者らが常に壁に乫きあたるのは，岩石の穿 孔試験における各種穿孔条件, すなわちあるビット型式 に対するスラスト, 回転数, 給水量などと穿孔速度との 関係を明確に追求することの困難さであった。

本報では穿孔条件と穿孔速度との関連性を比較的簡単 にしかも明瞭にあらわす方法の一知見を得たので, てれ について報告する。

\section{2. 実験装置ならびに供試岩石}

ボーリングの試験には, 釷研試錐工業株式会社製 $\mathrm{P} E$ 型を改装し，コップ式無段変速装置, 機械式トルク検出 装置を新たに取りつけた試錐機を使用した。

使用したビットは，J I S 規格の $36 \mathrm{~mm}$ タルコアビ ットに $5 \times 5 \times 8 \mathrm{~mm}$ の大をさのメタルチップ 6 個を斜 め縦植えに植付けたもので, 妇先角度は $90^{\circ}$, 逃证角は $25^{\circ}$ であり，チップ材質は $\mathrm{G}-2$ 相当品である。

給水は $20 l / \mathrm{min}$ のダブルヘリカルギヤーポンプでお こない, をた必要に応じ水道水を直接使用した。

供試岩石は東北石材株式会社産の輝石安山岩であって, その物理的性質を第 1 表に示す。

第 1 表 供試岩石の物理的性質

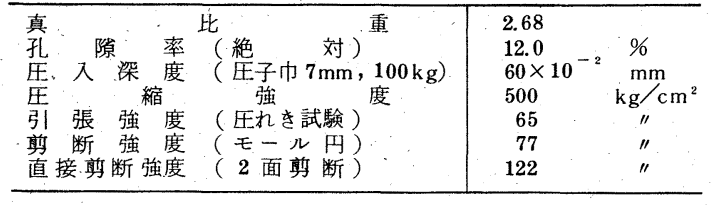

\section{3. 実験結果および結果の検討}

筆者らがおこなった穿孔試験の結果を第 1 図に示す。
この図はビット回転数を一定にしスラストと穿孔速度と の関係を示したものである。スラストと穿孔速度とは比 例な関係にあるととは明らかである。

次にスラストを一定にして回転数と穿孔速度との関係 を示せば第 2 図のよ5になる。回転数が増せば穿孔速度 も增大することがわかる。

しかしてれらの図から，スライムづまりやビット摩耗 その他の影響要素のため定性的なととは判っても定量的 な穿孔速度と穿孔条件との関係を求めることは困難であ り，また穿孔特性を求めることはできない。

穿孔速度とスラストおよび回転数相互の関係を一つの 図で示されれば便利である。乙れらの相関関係について 佐々木, 山門, 塩原, 戸辺らの研究 ${ }^{1)}$ がある。彼らは夕 イヤモンド・コアビットによる穿孔試験によって近似的に

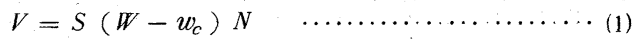
なる関係式の成立するとと䒠験的に求めた。(1)式で $V$ は穿孔速度, $S$ はスラスト $1 \mathrm{~kg}, 1$ 回転に対する穿孔 長を示す穿孔速度指数，Wはスラスト， $w_{c}$ は限界スラ スト， $N$ はビット回転数である。

(1)式はまた次のよらになる。すなわち

$$
\frac{V}{N}=S\left(W-w_{c}\right)
$$

(2)式は， $V / N$ と $W$ との関係は直線であり，その直線の 傾斜が $S$, 直線とW 軸との交点が $w_{c}$ であるととを示し ている。

筆者らの穿孔試験結果を $V / N$ と $W$ とについて図示すれ ば第 3 図のよ5にスラストが $150 \mathrm{~kg}$ 以上から直線とな る実線とこの線から分岐する 3 本の破線で示した曲線が 求められた。

(1)式は筆者らの穿孔試験結果に適用でき，しかも $V / N$ 対Wの関係から穿孔特性を容易に求めることができる。 すなわち佐々木らの提案した穿孔速度指数と限界ス ストは, 筆者らの供試岩石ではそれぞれ $0.88 \times 10^{-2} \mathrm{~cm}$, 


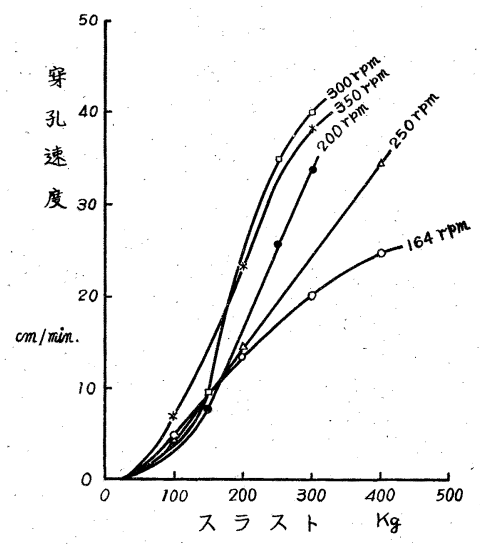

第1図 各回転数に対するスラストと 穿孔速度との関係

$105 \mathrm{~kg}$ となる。

またての穿孔特性直線は, 次のような非常に有効な知 見を与える。

(1) 直線の傾斜の緩急によって穿孔する岩石に最も適 した型式のビットの選定ができる。

(2) 穿孔条件がその岩石に対し適切であったかどらか を直ちに知ることがでをるばかりでなく，不適切な原因 の追求が容易になる。

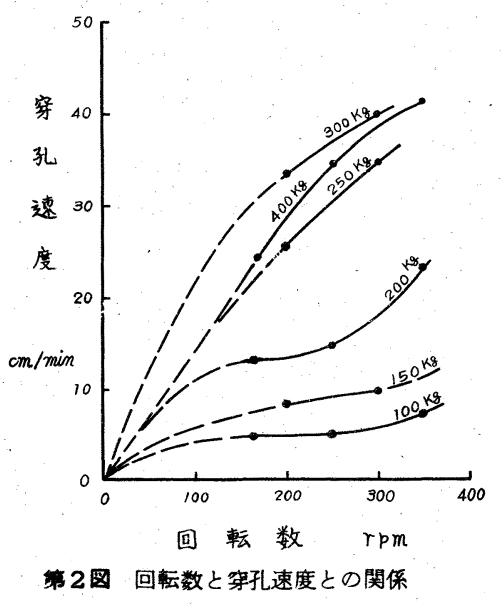

（3）岩石の物理的性質と穿孔性との関連を見出すとと が容易になるであろう。

今後の大をな課題としては，ての穿孔特性直線がフィ ールドにおいて適用できるか否かである。

\section{参考文献}

1）佐々木和郎・山門憲雄・塩原善一・戸辺雅行：ボーリングに関 する研究, 日本鉱業会誌, 76 巻, 860 号, 昭和 35 年 2 月, $75 \sim 82$ 頁

\section{6 三井レンジングドラムカッタについて}

\section{1. 緒言}

昨年 3 月全炭技創立 20 週年記念東京大会におらて紹 介された資料によれば

昭 40-3：ホーベル：稼働／在籍 $=68 / 106$,

$$
\text { ドラム: 稼働 } / \text { 在籍 }=52 / 73
$$

昭 41-3：ホーベル：稼働 /在籍 $=59 / 122$,

$$
\text { ドラム : 稼働 / 在籍 }=61 / 96
$$

と, ドラム採炭がホーベル採炭を，上廻りつつある。乙 の原因として考えられる要素としては次の3 項目がある。

(1) 硬質炭切截に適し，払条件との適応性がより高い。

(2) 山丈規制可能, 払進行一定のため自走枠との適合性 大。

(3) ドラムカッタの高性能化（レンジングの出現）。

今後, 自走枠の普及飞伴って, 本傾向はますます增大 すると思われるが，特にダブルレンジングの発展は目覚 ましい。

\section{2. 三井ドラムカッタの実績}

䌘社は昭和. 34 年わが国初のドラムカッタ製作以来,

\begin{tabular}{|c|c|c|}
\hline 型 & 1 号機製作年月 & 納入台数 備 \\
\hline MCLE 100 - DS 5452 型 & S $34-7$ 末 & 30 台（薄層用） \\
\hline $\mathrm{MW}-54 \mathrm{E}$ D型 & S $38-9$ 末 & $\begin{array}{l}10 \text { 台 } \\
\text { (ダブルドラム) }\end{array}$ \\
\hline MCLE 120 - DH5452 型 & S 40 - 3 末 & $\begin{array}{l}20 \text { 台 } \\
\text { (ヘリカルドラム) }\end{array}$ \\
\hline
\end{tabular}
下記の各型式を製作，好評裡にご使用頂いている。

*厂切羽支保の推移々自走支保切羽の実績」(1967 炭坑新技術)
三井三池製作所技術部 三 輪 了(正会員)

$$
\begin{gathered}
\text { MCLE 200 - DR8090 型：S41-9末 c } \begin{array}{c}
5 \text { 台 } \\
\text { (シンクルレンシンク) }
\end{array} \\
\text { MCLE 270 - DR8095 型：S41-10末 c } 4 \text { 台 } \\
\text { (ダブルレンシンク) }
\end{gathered}
$$$$
\text { 計 } 69 \text { 台 }
$$

乙の他, 現在受註製作中のレンシシングドラムカッタ数 台あり, 今後の主力機はダブルレンジング型となろらと している。

\section{3. 三井レンジングドラムカッタの考え方}

三井レンシシングドラムカッタを計画する場合に参考と した実績のあるレンジングドラムカッタとして次の機種 がある。

$\mathrm{AB}$ 社(英)：Sixteen Ranging Drum Shearer

" : Double Ended Renging Drum

Eickhoff : EDW-130L S ingle Ranging Drum

(西独) : EDW-340L Twin Ranger

$$
\text { ": EDW-200 Double Drum S.L. }
$$

これらの各型式の長所を比較検討した結果, 計画にあ たっては、下記の方針でまとめるとととした。

(1) 機長および機高

A B 社の短機長, 高機高型より, E 社の低機高, 長 機長型を採用した。

(2) 了一ム型式

$\mathrm{A} B$ 社型は,ドラム軸の支持が強固となる反面, 払 コンベヤの流炭の障害となり, 特に自走枠と併用の場合 支保メンバーとの干渉の恐れあるためにカンチレバー式 の $\mathrm{E}$ 社方式を採用七市 (第 1 図参照)。 